\title{
Superoxide Dismutase Activity in Lymphocytes and Polymorphonuclear Cells of Diabetic Patients
}

\author{
Marijana Vučić ${ }^{1}$, Mirjana Gavella ${ }^{1}$, Veljko Božikov ${ }^{2}$, Stephen J. H. Ashcroft ${ }^{3}$ and Boris Ročić ${ }^{1}$ \\ ${ }^{1}$ Department of Laboratory Medicine, Vuk Vrhovac University Clinic for Diabetes, Endocrinology and Metabolic \\ Diseases, Medical Faculty, University of Zagreb, Zagreb, Croatia \\ 2 Dubrava University Hospital, Medical Faculty, University of Zagreb, Zagreb, Croatia \\ ${ }^{3}$ Nuffield Department of Clinical Biochemistry, John Radcliffe Hospital, Oxford, UK
}

Summary: Copper-zinc superoxide dismutase ( $\mathrm{Cu}, \mathrm{Zn}$-superoxide dismutase) activity was evaluated in lymphocytes and polymorphonuclear cells of insulin-dependent $(n=33)$ and non-insulin-dependent $(n=34)$ diabetic patients. A commercial method for the measurement of superoxide dismutase activity was adapted for use on a discrete analyser and evaluated for interference by other antioxidants with superoxide anion-scavenging properties. In comparison to healthy control subjects $(\mathrm{n}=32)$, a significantly lower $\mathrm{Cu}, \mathrm{Zn}$-superoxide dismutase activity was found in both lymphocytes and polymorphonuclear cells of insulin-dependent $(2.08 \pm 0.58 \mathrm{vs.} 1.70 \pm 0.46 \mathrm{U} / \mathrm{mg}$ protein, $\mathrm{p}<0.05$, and $1.06 \pm 0.46$ vs. $0.64 \pm 0.40 \mathrm{U} / \mathrm{mg}$ protein, $\mathrm{p}<0.001$, respectively) and non-insulin-dependent diabetic patients $(2.08 \pm 0.58$ vs. $1.61 \pm 0.48 \mathrm{U} / \mathrm{mg}$ protein, $\mathrm{p}<0.01$, and $1.06 \pm 0.46 \mathrm{vs.} 0.53 \pm 0.24 \mathrm{U} / \mathrm{mg}$ protein, $\mathrm{p}<0.001$, respectively). There was a weak, but significant negative correlation between age and $\mathrm{Cu}, \mathrm{Zn}$-superoxide dismutase activity in lymphocytes and polymorphonuclear cells $(r=-0.22$ and $r=-0.28, p<0.05$, respectively), whereas no influence of gender, diabetes duration and glycaemic control was observed. The results indicate that diabetes mellitus could elicit a significant disturbance in superoxide anion-scavenging potential of lymphocytes and polymorphonuclear cells.

\section{Introduction}

It has been suggested that oxidative stress, associated with diabetes mellitus, might play an important role in the initiation and progression of diabetic complications $(1,2)$. Although increased production of toxic free radicals in experimental and human diabetes is well documented (3), it is likely that diminished activity of the antioxidant defence system(s) contributes significantly to the development of oxidative stress (4). Overall antioxidant defence of eukaryotic cells is provided by a variety of enzymatic and non-enzymatic system(s) (5). Copper-zinc superoxide dismutase ${ }^{1}$ ) in the cytoplasm and manganese superoxide dismutase ${ }^{1}$ ) in the mitochondria act as key intracellular scavengers, catalysing dismutation of commonly produced superoxide anion radicals to hydrogen peroxide and molecular oxygen (6).

Both unchanged and diminished $\mathrm{Cu}, \mathrm{Zn}$-superoxide dismutase activity in erythrocytes of diabetic patients have been reported and there are conflicting results regarding the influence of glycaemic control on dismutase activity (7-9). It was clearly demonstrated that erythrocyte su-

1) Enzymes:

Superoxide dismutase (superoxide : superoxide oxidoreductase; EC 1.15.1.1)

Xanthine oxidase (xanthine : oxygen oxidoreductase; EC 1.1.3.22) peroxide dismutase activity was significantly decreased by in vitro, as well as in vivo glycation (10). There is little evidence, however, concerning the scavenging potential of the circulating immune cells of diabetic patients, especially regarding the well documented impairment of the immune system in diabetes mellitus and its proposed role in the development of diabetic complications $(2,11)$.

A variety of methods used for the measurement of superoxide dismutase activity are insufficiently standardised and not easily adaptable for automatic determination. A modification of the xanthine/xanthine oxidase $\left.{ }^{1}\right)$ method, using the dye 2-(p-indophenyl)-3-( $p$-nitrophenol)-5-phenyl tetrazolium chloride (I.N.T.) (12), was applied recently in the development of an assay for the measurement of superoxide dismutase activity in erythrocytes by Randox Laboratories.

The aim of this study was to adapt the assay for the automated measurement of $\mathrm{Cu}, \mathrm{Zn}$-superoxide dismutase activity in lymphocytes and polymorphonuclear cells of diabetic patients by the use of a discrete analyser. Special emphasis was given to the evaluation of the possible contribution of other physiologically relevant superoxide anion scavenging compounds to the assay. 


\begin{abstract}
Methods
Lymphocytes and polymorphonuclear cells were isolated from fasting EDTA blood samples $(10 \mathrm{ml})$ according to Boyum with slight modifications (13). Leukocytes were obtained from the blood with dextran T-500 (Pharmacia, Uppsala, Sweden, $60 \mathrm{~g} / \mathrm{l}$ ), after sedimentation of erythrocytes $\left(45 \mathrm{~min}, 25^{\circ} \mathrm{C}\right)$. Lymphocytes and polymorphonuclear leukocytes were separated by centrifugation $(400 \mathrm{~g}$, $40 \mathrm{~min})$ over Ficoll-Paque $(\mathrm{d}=1.077 \mathrm{~kg} / \mathrm{l}$, Pharmacia, Uppsala, Sweden). After lysis of remaining erythrocytes and platelets (cold EDTA, $10 \mathrm{mmol} / 1$, Kemika, Zagreb, Croatia) and restoring of isotonicity $(\mathrm{NaCl}, 18 \mathrm{~g} / \mathrm{l}$, Kemika, Zagreb, Croatia), lymphocytes and polymorphonuclear cells were washed (phosphate buffered saline, pH 7.4, 3×), resuspended in Hank's buffered salt solution (Sigma, St. Louis, USA), and lysed by the repeated cold shock procedure (three times freezing at $-20^{\circ} \mathrm{C}$, followed by subsequent thawing at $37^{\circ} \mathrm{C}$ ). Clear supernatants were collected after centrifugation $(1500 \mathrm{~g}, 15 \mathrm{~min})$ and frozen $\left(-20^{\circ} \mathrm{C}\right)$ until analysed. Pooled cell lysates were used for the stability and precision studies.
\end{abstract}

$\mathrm{Cu}, \mathrm{Zn}$-superoxide dismutase activity was measured using the commercial RanSod reagent kit (Randox, Crumlin, Antrim, UK), originally designed for the determination of superoxide dismutase in erythrocytes. Superoxide anion radicals, generated by the xanthine/ xanthine oxidase system, react with electron acceptor $2-(p$-indophenyl)-3-(p-nitrophenol)-5-phenyl tetrazolium chloride (I. N. T.) forming a red formazan dye (absorbance at $500 \mathrm{~nm}$ ). Superoxide dismutase activity is measured by the degree of inhibition of this reaction. The assay was modified for automatic measurement on a discrete analyser (Spectrum-High Performance Diagnostic System, Abbott, Chicago, USA). In order to increase assay sensitivity for the measurement of $\mathrm{Cu}, \mathrm{Zn}$-superoxide dismutase activity in lymphocytes and polymorphonuclear cells, an automated procedure using 3.5 times larger sample volumes was designed. The assay was performed by mixing the xanthine/I.N.T. reagent $(236 \mu \mathrm{l})$ with $25.0 \mu \mathrm{l}$ of cell lysate, initiating the reaction by subsequent addition of xanthine oxidase $(34.6 \mu \mathrm{l}, 80 \mathrm{U} / \mathrm{l})$. The absorbance was measured after incubation $\left(37^{\circ} \mathrm{C}, 180 \mathrm{~s}, 500 \mathrm{~nm}\right)$ and corrected for the non-specific reduction of I.N.T. by other lysate components (sample blank). Absorbances were converted into the percentage of inhibition of the reaction, using reagent blank as $100 \%$ (uninhibited reaction). The assay was calibrated using superoxide dismutase standard $(5.4 \mathrm{kU} / \mathrm{l})$ provided by the manufacturer; $1 \mathrm{U}$ is defined as the enzyme activity causing $50 \%$ inhibition of the rate of I.N.T. reduction under assay conditions (12). For the automated procedure with increased sensitivity, dilutions of the standard in phosphate buffered saline, $\mathrm{pH} 7.4(0.064,0.189,0.375,0.750$ and $1.50 \mathrm{kU} / \mathrm{l}$, respectively) were found to cover appropriately reaction inhibition ranging from $15-85 \%$, and used for the construction of the standard curve [log SOD (kU/l) vs. \% inhibition]. Absorbances obtained from cell lysates using this modified procedure gave inhibitions ranging from $30-70 \%$, as recommended in the original assay (12).

Inhibition of $\mathrm{Cu}, \mathrm{Zn}$-superoxide dismutase with $\mathrm{KCN}(2.0 \mathrm{mmol} / \mathrm{l}$, Kemika, Zagreb, Croatia) was used to examine the possible presence of Mn-superoxide dismutase in cell lysates obtained with the cold-shock procedure. Interference by other antioxidants with possible superoxide dismutase-like activity was evaluated by assaying saline solutions of albumin, IgG, uric acid, ascorbic acid (all from Sigma, St. Louis, USA) and soluble tocopherol analogue 6-hydroxy-2,5,7,8-tetramethylchroman-2-carboxylic acid (Aldrich, Milwaukee, USA).

Total protein content in cell lysates was measured by Bradford's method (14).

Ascorbic acid in cell lysates was measured by the colorimetric method with a detection limit of $6 \mu \mathrm{mol} / 1$ (15) using commercially available reagents (Boehringer, Mannheim, Germany).

$\mathrm{HbA}_{1 \mathrm{c}}$ was measured by ion-exchange chromatography (16), using FPLC system (Pharmacia, Uppsala, Sweden), and fasting blood glucose was determined with glucose-oxidase method using commercially available reagents (Boehringer, Mannheim, Germany).
All data are expressed as mean values \pm S.D. After testing for normality, comparisons of means were made by one-way analysis of variance (ANOVA) using CSS software (StatSoft Inc., Tulsa, USA), followed by Tukey's multiple-comparison procedure in order to determine which population means are different. Multiple regression analysis was performed to evaluate the relationship between variables. The differences were considered as statistically significant at $\mathrm{p}$ less than 0.05 .

\section{Subjects}

After informed consent was obtained, blood samples were collected from 67 diabetic subjects without clinically evident complications, classified as insulin-dependent $(n=33)$ and non-insulin-dependent $(n=34)$ diabetic patients (17). Additionally, control blood samples were collected from healthy individuals $(n=32)$. Characteristics of the study groups are presented in table 1.

\section{Results}

The evaluation of the automated assay for $\mathrm{Cu}, \mathrm{Zn}$-superoxide dismutase activity in lymphocytes and polymorphonuclear cells gave intra- $(\mathrm{n}=10)$ and inter-assay $(\mathrm{n}=20)$ imprecision $(\mathrm{CV})$ of $3.91 \%$ and $5.0 \%$, respectively, whereas sensitivity and linearity were limited with the range of the standard dilutions used for the appropriate covering of the degree of reaction inhibition, amounting to $0.064 \mathrm{kU} / 1$ and $1.5 \mathrm{kU} / 1$. Sample storage for four $\left(-20^{\circ} \mathrm{C}\right)$ or eight $\left(-80^{\circ} \mathrm{C}\right)$ weeks did not influence assay results. The addition of superoxide dismutase from bovine erythrocytes (EC 1.15.1.1, Sigma, St. Louis, USA) to cell lysates resulted in $102 \%$ and $96 \%$ recovery at the levels of activity of $0.28 \mathrm{kU} / 1$ and 1.16 $\mathrm{kU} / 1$, respectively $(\mathrm{n}=5)$. The enzyme activity was found to be 91 and $95 \%$ preserved after saline solutions of superoxide dismutase $(0.50$ and $1.20 \mathrm{kU} / \mathrm{l}$, respectively, $n=5$ ) were subjected to the cold-shock procedure. Superoxide dismutase activity in cell lysates was $100 \%$ inhibited by $\mathrm{KCN}(2.0 \mathrm{mmol} / \mathrm{l})$, indicating that no mitochondrial $\mathrm{Mn}$-superoxide dismutase was released by the cold-shock procedure.

The investigation of the possible contribution of physiologically relevant antioxidants to the assay showed that only ascorbate at the upper level of the physiological concentration in lymphocytes $[700 \mu \mathrm{mol} / \mathrm{l}$, as reported by Lee et al. (18)], exhibited low superoxide dismutaselike activity $(0.19 \mathrm{kU} / 1)$, whereas no detectable activity was elicited by saline solutions of albumin, IgG, uric acid and 6-hydroxy-2,5,7,8-tetramethylchroman-2-carboxylic acid $(20 \mathrm{~g} / \mathrm{l}, 3 \mathrm{~g} / \mathrm{l}, 0.5 \mathrm{mmol} / \mathrm{l}$ and $25 \mathrm{mmol} / \mathrm{l}$, respectively). However, no ascorbate was measured in lysates of lymphocytes and polymorphonuclear cells, obtained by the repeated cold-shock procedure.

$\mathrm{Cu}, \mathrm{Zn}$-superoxide dismutase activities measured in lymphocytes and polymorphonuclear cells isolated from the blood of diabetic patients and healthy controls were normalised to the total protein content of cell lysates. Dismutase activities from both cell types were not found to 
Tab. 1 Characteristics of the study groups

\begin{tabular}{llllllr}
\hline Subjects & $\mathrm{n}$ & Gender & Age & Duration & $\begin{array}{c}\mathrm{HbA}_{1 \mathrm{c}} \\
\text { (\%) }\end{array}$ & $\begin{array}{l}\text { Plasma } \\
\text { glucose } \\
(\mathrm{mmol} / \mathrm{l})\end{array}$ \\
\hline $\begin{array}{l}\text { Healthy controls } \\
\begin{array}{l}\text { Patients with insulin-dependent } \\
\text { diabetes mellitus }\end{array}\end{array}$ & 32 & $15 / 17$ & $39 \pm 7.5$ & - & $4.2 \pm 0.9$ & $4.7 \pm 1.8$ \\
$\begin{array}{l}\text { Patients with non-insulin-dependent } \\
\text { diabetes mellitus }\end{array}$ & 34 & $16 / 17$ & $37 \pm 8.8$ & $10.4 \pm 9.2$ & $8.6 \pm 2.7$ & $10.3 \pm 3.8$ \\
\hline
\end{tabular}

be influenced by gender, smoking habits and duration of the disease. Simple correlation analysis found a weak but significant negative relationship between age and $\mathrm{Cu}, \mathrm{Zn}$-superoxide dismutase activity in lymphocytes and polymorphonuclear cells $(r=-0.22, p<0.05$ and $r=-0.28, p<0.05$, respectively, figs 1 and 2). Multiple regression analysis identified age as a significant determinant of lymphocyte $\left(\mathrm{t}=-2.11, \mathrm{R}^{2}=0.05\right.$, $\mathrm{p}=0.04) \quad$ and polymorphonuclear $\quad(\mathrm{t}=-2.58$, $\left.\mathrm{R}^{2}=0.08, \mathrm{p}=0.01\right)$ SOD activity in the diabetic subjects, whereas no influence of diabetes duration, blood glucose and $\mathrm{HbAlc}$ was found.

Significantly lower $\mathrm{Cu}, \mathrm{Zn}$-superoxide dismutase activity was found in lymphocytes of both insulin-dependent and non-insulin-dependent diabetic patients when compared to control subjects $(1.69 \pm 0.45$ and $1.61 \pm 0.48$ vs.

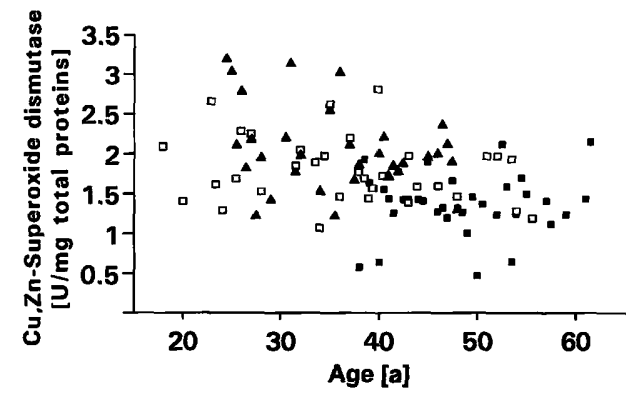

Fig. 1 Relation between age (years) and $\mathrm{Cu}, \mathrm{Zn}$-superoxide dismutase activity (U/mg total protein) in lymphocytes of the patients with insulin-dependent $(\square, n=33)$, non-insulin dependent diabetes mellitus $(\square, n=34)$ and healthy control subjects $(\Delta, n=32)$.

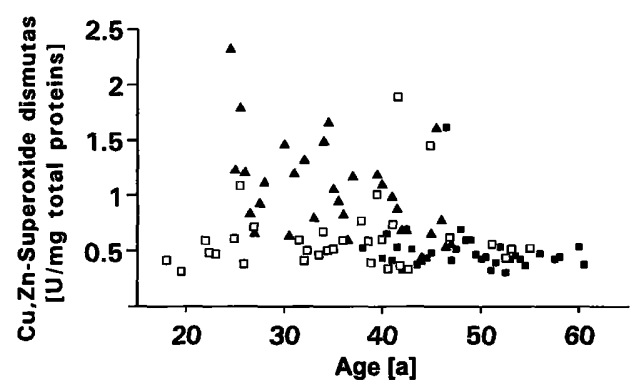

Fig. 2 Relation between age (years) and $\mathrm{Cu}, \mathrm{Zn}$-superoxide dismutase activity (U/mg total protein) in polymorphonuclear leukocytes of the patients with insulin-dependent $(\square, n=33)$, non-insulin dependent diabetes mellitus $(\boldsymbol{\square}, \mathrm{n}=34)$ and healthy control subjects $(\Delta, \mathrm{n}=32)$.
$2.06 \pm 0.58 \mathrm{U} / \mathrm{mg}$ total protein, $\mathrm{p}<0.05$, respectively). An even more significant difference was observed in polymorphonuclear cells of patients with insulin-dependent and non-insulin-dependent diabetes when compared to controls $(0.62 \pm 0.39$ and $0.51 \pm 0.24$ vs. 1.06 $\pm 0.43 \mathrm{U} / \mathrm{mg}$ total protein, $\mathrm{p}<0.001$, respectively). Dismutase activities in both cell types were higher in insulin-dependent than non-insulin-dependent subjects, but the difference was not significant. Although the subjects with non-insulin-dependent diabetes were older than those with insulin-dependent diabetes and healthy controls, and age was identified as an independent factor, adjusting for age did not affect the difference in the $\mathrm{Cu}, \mathrm{Zn}$-superoxide dismutase activity between the subjects studied (fig. 3).

\section{Discussion}

Persistent hyperglycaemia correlates highly with the development of late diabetic complications (19). However, the mechanisms involved in the progression of retinopathy, neuropathy and nephropathy are still unclear. A large body of evidence suggests that oxidative stress might play a significant role in the development of diabetic complications. The mechanisms connecting hyperglycaemia and oxidative stress implicate a complex cyclic interaction between glucose auto-oxidation, gly-

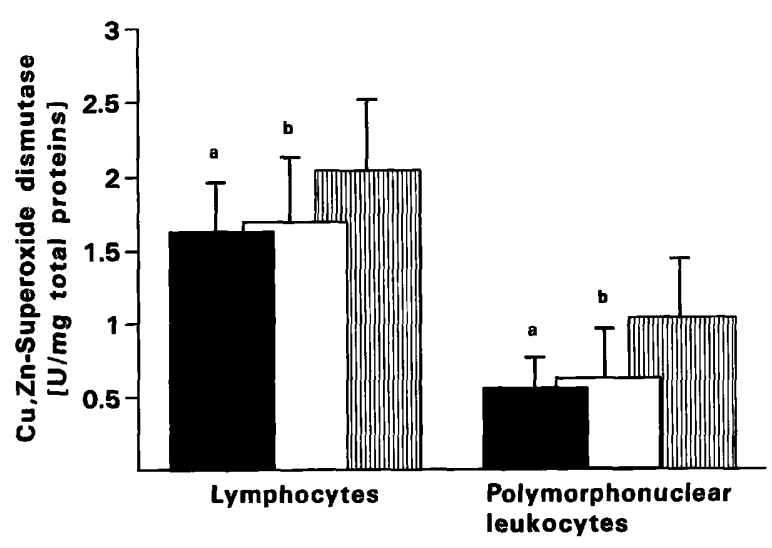

Fig. 3 Age-adjusted $\mathrm{Cu}, \mathrm{Zn}$-superoxide dismutase activity (U/mg total protein) in lymphocytes and polymorphonuclear leukocytes in 33 patients with insulin-dependent $\square, 34$ patients with non-insulindependent diabetes mellitus $\square$ and 32 healthy control subjects $\mathbf{m}$. Levels of significance: ${ }^{\mathrm{a}} \mathrm{p}<0.05,{ }^{\mathrm{b}} \mathrm{p}<0.001$ vs. healthy controls. 
cation of proteins and oxidation of associated lipids (1, 2). Generation of oxygen free radicals during these interactions has been confirmed by the findings of increased superoxide anion radical production in both plasma and polymorphonuclear leukocytes of diabetic patients $(20,21)$. Although superoxide dismutases provide effective intracellular defence against superoxide radical-mediated toxicity, this scavenging system might be impaired in diabetes due to diminished synthesis and/ or deactivation of the enzymes by glycation (10). Attempts to evaluate the superoxide dismutase activity in diabetic patients demonstrated inconsistent results $(7-9)$.

This could, at least in part, be attributable to the unstandardised methodology applied to the measurements of superoxide dismutase activity. In the present study a rapid, simple and reliable automated procedure for the measurement of $\mathrm{Cu}, \mathrm{Zn}$-superoxide dismutase activity in lymphocytes and polymorphonuclear cells is described. The procedure can be applied to the measurement of superoxide dismutase activity in various biological systems $(22,23)$. Increased sensitivity of the measurement enables sufficient cell isolation from as little as $10 \mathrm{ml}$ of whole blood. No interference from mitochondrial Mnsuperoxide dismutase and other physiologically relevant antioxidants, with the exception of ascorbic acid, was detected. Nevertheless, no ascorbate was detected in the cell lysates, and it was presumed that ascorbate, due to its unstability, underwent degradation during cell isolation and lysis by the cold-shock procedure. Thus, ascorbate interference in this assay seems unlikely.

The results of this study indicate that $\mathrm{Cu}, \mathrm{Zn}$-superoxide dismutase activity is significantly lower in circulating immune cells of insulin-dependent and non-insulin-dependent diabetic patients, when compared to healthy controls. The results obtained in polymorphonuclear cells are in accordance with the previous observation in newly diagnosed, unclassified diabetic patients (21), exhibiting for the first time that a decrease of $\mathrm{Cu}, \mathrm{Zn}$ superoxide dismutase activity persists in both insulindependent and non-insulin-dependent diabetic patients. Furthermore, these findings are supported by the recent report on diminishing polymorphonuclear dismutase activity in the course of the development of insulin-dependent diabetes mellitus in first-degree relatives of diabetic patients (24). Significantly lower $\mathrm{Cu}, \mathrm{Zn}$-superoxide dis-

\section{References}

1. Baynes J. Role of oxidative stress in development of complications in diabetes. Diabetes 1991; 40:405-12.

2. Thornalley PJ. Advanced glycation and the development of diabetic complications. Unifying the involvement of glucose, methylglyoxal and oxidative stress. Endocrinol Metab 1996; 3:149-66.

3. Obereley LW. Free radicals and diabetes. Free Radic Biol Med 1988; 5:113-24. mutase activity in lymphocytes of diabetic patients confirms our preliminary report on the impaired antioxidant defence in insulin-dependent diabetes (25), indicating that diabetes itself, regardless of the type, might elicit disturbances in the cellular protection against superoxide radical-mediated toxicity. Although unchanged lymphocyte superoxide dismutase activity in diabetic children has been reported (26), our results obtained in the group of adult patients may not necessarily be discrepant since, considering the significant negative correlation between age and $\mathrm{Cu}, \mathrm{Zn}$-superoxide dismutase activity, it is likely that both the ageing process and diabetes mellitus might be involved in the decrease of the enzyme activity. The lack of influence of blood glucose and $\mathrm{HbAlc}$ on $\mathrm{Cu}, \mathrm{Zn}$-superoxide dismutase activity, apart from the relatively short life span of leukocytes, indicates that the decreased activity in lymphocytes and polymorphonuclear leukocytes could hardly be ascribed to the time-requiring process of enzyme glycation, as it was suggested for the dismutase in the erythrocytes (10).

Diminished $\mathrm{Cu}, \mathrm{Zn}$-superoxide dismutase activity in lymphocytes and polymorphonuclear cells of diabetic patients could also indicate a complex disturbance of immune cell metabolism in diabetes mellitus, affected by both hyperglycaemia and hypoinsulinaemia (11). It is important to emphasize that diabetic patients did not have evident complications at the time of the study, suggesting that the impairment of defence systems against superoxide radical-mediated toxicity in circulating immune cells precedes the clinical onset of complications. Whether or not this defence system is involved in the progression of diabetic complications remains to be further elucidated. Functional and biochemical investigations of circulating immune cells offer a plausible experimental model for in vitro studies of both immunological and metabolic alterations in diabetes mellitus which may lead to the development of diabetic complications. The measurement of $\mathrm{Cu}, \mathrm{Zn}$-superoxide dismutase activity by the use of a rapid, simple and reliable automated procedure is likely to be a valuable tool in attaining this goal.

\section{Acknowledgements}

The authors are grateful to Dr. Gojka Roglić for critically reviewing this manuscript.

4. Thompson $\mathrm{KH}$, Godin DV. Micronutrients and antioxidants in the progression of diabetes. Nutr Res 1995; 15:1377-410.

5. Halliwell B. Free radicals, antioxidants and human disease: curiosity, cause or consequence? Lancet $1994 ; 344: 721-4$.

6. Fridovich I. Superoxide dismutases. Ann Rev Biochem 1975; 44:147-59.

7. Bono A, Caimi G, Catania A, Sarno A, Pandolfo L. Red cell 
peroxide metabolism in diabetes mellitus. Horm Metab Res 1987; 19:264-6.

8. Leonard MB, Lawton K, Watson ID, Patrick A. Walker A, MacFarlane I. Cigarette smoking and free radical activity in young adults with insulin-dependent diabetes. Diabet Med $1995 ; 12: 46-50$.

9. Tho LL, Candlish JK, Thai AC. Correlates of diabetic markers with erythrocytic enzymes decomposing reactive oxygen species. Ann Clin Biochem 1988; 25:426-31.

10. Oda A, Banai C, Yamaoka T, Katori T, Matsushima T, Yamashita $\mathrm{K}$. Inactivation of $\mathrm{Cu}, \mathrm{Zn}$-superoxide dismutase by in vitro glycosylation and in erythrocytes of diabetic patients. Horm Metab Res 1994; 26:1-4.

11. Moutschen MP, Scheen AJ, Lefebvre PJ. Impaired immune responses in diabetes mellitus: analysis of the factors and mechanisms involved. Diabet Metab 1992; 18:187-201.

12. Arthur JR, Boyne R. Superoxide dismutase and glutathione peroxidase activities in neutrophils from selenium deficient and copper deficient cattle. Life Sci 1985; 36:1569-75.

13. Boyum A. Isolation of mononuclear cells and granulocytes from human blood. J Clin Lab Invest (Suppl) 1968; 21:77-89.

14. Bradford MM. A rapid and sensitive method for the quantitation of microgram quantities of protein utilizing the principle of protein-dye binding. Anal Biochem 1976; 72:248-54.

15. Deneke U, Michal G, Beutler H-O. Neue Methode zur Bestimmung von Vitamin $\mathrm{C}$ in Lebensmitteln. Dtsch LebensmRundsch 1978; 74:400-3.

16. Jeppson J-O, Jerntorp P, Sundkvist G, Englund H, Nylund V. Measurement of $\mathrm{HbAlc}$ by a new liquid-chromatographic assay: methodology, clinical utility and relation to glucose tolerance evaluated. Clin Chem 1986; 32:1867-72.

17. Diabetes Mellitus. Report of a WHO Study Group, Geneva Switzerland, 1985 (WHO Technical Report Series, No. 727).

18. See W, Hamernyik $P$, Hutchinson M. Ascorbic acid in lymphocytes: cell preparation and liquid-chromatographic assay. Clin Chem 1982; 28:2165-9.
19. Pirart J. Diabetes mellitus and its degenerative complications: a prospective study of 4400 patients observed between 1947 and 1973. Diab Care 1987; 1:168-263.

20. Ceriello A, Giuliano D, Quatraro A, Dello Russo P, Lefebvre PJ. Metabolic control may influence the increased superoxide generation in diabetic serum. Diab Med 1991; 8:540-2.

21. Nath N, Chari SN, Rathi AB. Superoxide dismutase in diabetic polymorphonuclear leukocytes. Diabetes $1984 ; 33: 586-9$.

22. Gavella M, Lipovac V, Vučić M, Ročić B. Superoxide anion scavenging capacity of human seminal plasma. Int $\mathbf{J}$ Androl 1996; 19:82-90.

23. Gavella M, Lipovac V, Vučić M, Ročić B. Relationship of sperm superoxide dismutase-like activity with other spermspecific enzymes and experimentally induced lipid peroxidation in infertile men. Andrologia 1996; 28:223-9.

24. Vučić M, Ročić B, Knežević-Cuća J, Profozić, V, Pavlić-Renar I, Radica A, et al. Antioxidative defence in ICA-positive firstdegree relatives of type 1 diabetic patients. Diabetologia 1996; 39 (1 Suppl):A94.

25. Vučić M, Ročić B, Božikov V, Pavlić-Renar I, Mesić R, Knežević J, Metelko Ž. Lymphocyte superoxide dismutase activity and total plasma antioxidants in type 1 diabetes. Diabetologia 1995; 38 (1 Suppl):A252.

26. Hägglöf $B$, Marklund SL, Holmgren G. CuZn superoxide dismutase, Mn superoxide dismutase, catalase and glutathione peroxidase in lymphocytes and erythrocytes in insulindependent diabetic children. Acta Endocrinol 1983; 102:235-9.

\section{Received February 10/April 29, 1997}

Corresponding author: Marijana Vučić M. Sc, Department of Laboratory Medicine, Vuk Vrhovac University Clinic for Diabetes, Endocrinology and Metabolic Diseases, Dugi dol 4A, 10000 Zagreb, Croatia 
